\title{
COMPARATIVE ANALYSIS FOR TRADITIONAL YURTS USING THERMAL DYNAMIC SIMULATIONS IN MONGOLIAN CLIMATE
}

\author{
${ }^{1}$ Gantumur TSOVOODAVAA, ${ }^{2}$ István KISTELEGDI ${ }^{*}$ \\ ${ }^{1}$ Breuer Marcel Doctoral School, Faculty of Engineering and Information Technology \\ University of Pécs, Boszorkány u. 2, H-7624 Pécs, Hungary \\ and School of Civil Engineering and Architecture, Mongolian University of Science and \\ Technology, Ulaanbaatar, Mongolia, e-mail: ${ }^{1}$ tsovoog@gmail.com \\ ${ }^{2}$ Institute of Architecture, Faculty of Engineering and Information Technology \\ Boszorkány u. 2 and János Szentágothai Research Center, Ifjúság u. 20 \\ University of Pécs, H-7624 Pécs, Hungary, e-mail: kistelegdisoma@mik.pte.hu
}

Received 11 July 2018; accepted 27 December 2018

\begin{abstract}
The yurt is one of the ancient living units for the nomadic cultural country. The yurt is a nomadic vernacular architecture, which has been developed for 3000 years. There are 31 counties using the yurt, out of which 13 of them use their traditional yurt around the world. Basically, the yurt was used as residential housings and today, also to some extent, for commercial and touristic purposes under different climates. Analyzing existing literature, as well as scientific publications it is apparent that besides architectural and structural topics, there is no existing investigation or published paper about building physics analysis of these buildings. Current research aims to create a database about energy and climate comfort qualities of traditional yurts using dynamic calculation tools. As a result, to intend to learn from the traditional yurt technology and to develop a completely new and modern building prototype based on the yurt-experiments in next step of research. Firstly, finding optimal solutions for a contemporary yurt-building' should be applied under Mongolian climate conditions, since this form of housing is still used in this country, and, in addition, the comfort and energy performance of the yurts were surprisingly satisfactory under extreme weather conditions, by temperature differences between summer and winter of approx. $80 \mathrm{~K}$.
\end{abstract}

Keywords: Vernacular architecture, Nomadic country, Mongolian climate, Climate zone, Dynamic simulation, IDA ICE code, Energy, Thermal comfort, Indoor air quality

\footnotetext{
${ }^{*}$ Corresponding Author
} 


\section{Introduction}

There are nine different types of traditional yurts around the world, which are used in 31 countries, out of which 13 countries use its own traditional yurt [1], [2]. In this study, IDA ICE 4.8 thermal dynamic simulation tool was applied and the mathematical model was built through simulating different versions of a yurt in conjunction with various climate zones of Mongolia. The purpose of this paper is to find the optimal yurt shape in consideration of energy consumption and indoor comfort. Mongolia is one of the countries, which have the hardest climate due to its huge temperature variance between winter and summer [3]. Therefore believing that the optimal yurt version fits for Mongolian climate can be also applied to varying climate zones of the world with slight or appropriate modification.

\section{Climate conditions}

Mongolian climate has a very high-temperature difference between summer and winter in relation to the continental location [3]. Its territory consists of four main zones differing by natural conditions, including forest mountain, steppe mountain, steppe, and desert zone.

In below, Fig. 1 illustrates four zones as numbered by I, II, III and IV. Zone I refers to the coldest temperature and others are numbered according to its temperature in ascending direction.

In Table I climate and the geographic information is systemized on cases of chosen climate stations from all climate zones and subzones.

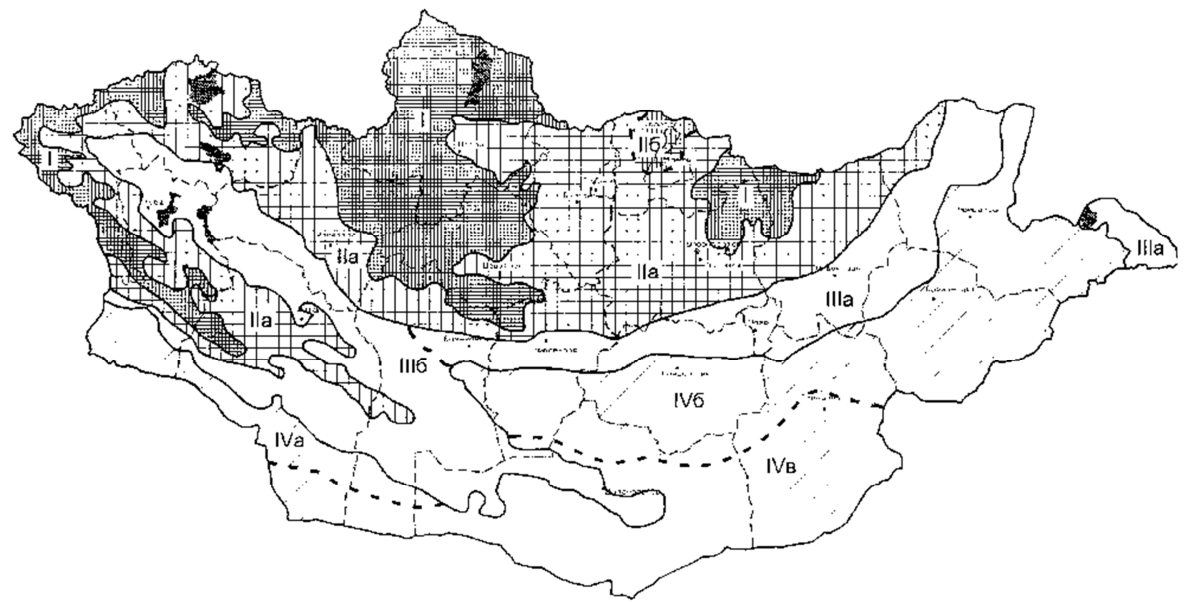

Fig. 1. Climate zones for urban planning [4].

For the simulation, Tosontsengel station from the $1^{\text {st }}$ climate zone was chosen, because it has the most extreme temperature difference and located in the north-west of 
Mongolia and highly elevated. In this area, the lowest peak temperature record was $53.0^{\circ} \mathrm{C}$ in 2006 and the maximum temperature was $33.8^{\circ} \mathrm{C}$ [4], [5].

Table I

Climate zones based on 'Meteonorm' climate database [5]

\begin{tabular}{|c|c|c|c|c|c|c|c|c|c|}
\hline 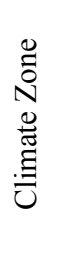 & $\begin{array}{l}\text { Ẽ } \\
\text { Z }\end{array}$ & 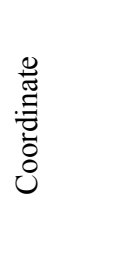 & 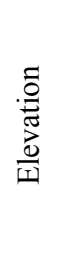 & 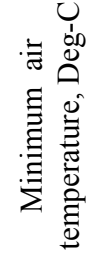 & 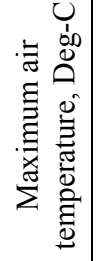 & 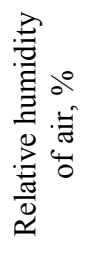 & 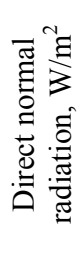 & 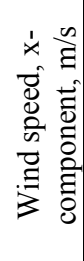 & 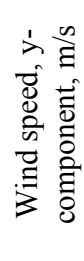 \\
\hline I. & Tosontsengel & $\begin{array}{l}48.7 \mathrm{~N} \\
98.3 \mathrm{~W}\end{array}$ & 2108 & -36 & 33 & 62.3 & 203.1 & -0.3 & 0.1 \\
\hline II.a. & Ulyastya & $\begin{array}{l}47.7 \mathrm{~N} \\
96.8 \mathrm{~W}\end{array}$ & 1753 & -36 & 33 & 60.0 & 211.6 & 0.0 & -0.1 \\
\hline II.b & Sukhbaatar & $\begin{array}{c}50.2 \mathrm{~N} \\
106.2 \mathrm{~W}\end{array}$ & 1124 & -35 & 34 & 70.1 & 194.2 & -0.2 & 0.0 \\
\hline III.a & Choir & $\begin{array}{c}46.4 \mathrm{~N} \\
108.4 \mathrm{~W}\end{array}$ & 1269 & -31 & 36 & 57.6 & 183.4 & -0.5 & 0.1 \\
\hline III.b & Altai & $\begin{array}{l}46.4 \mathrm{~N} \\
96.3 \mathrm{~W}\end{array}$ & 2213 & -35 & 28 & 67.4 & 213.8 & -0.5 & 0.1 \\
\hline IV.a & $\begin{array}{l}\text { Bulgan, } \\
\text { Khovd }\end{array}$ & $\begin{array}{l}46.1 \mathrm{~N} \\
91.5 \mathrm{~W}\end{array}$ & 1189 & -34 & 33 & 44.5 & 264.0 & -0.2 & 0.3 \\
\hline IV.b & Choibalsan & $\begin{array}{c}48.1 \mathrm{~N} \\
114.5 \mathrm{~W}\end{array}$ & 747 & -32 & 35 & 56.1 & 185.9 & -0.5 & 0.2 \\
\hline IV.c & Sainshand & $\begin{array}{c}44.9 \mathrm{~N} \\
110.1 \mathrm{~W}\end{array}$ & 961 & -28 & 39 & 51.8 & 269.7 & -0.6 & 0.2 \\
\hline City & Ulaanbaatar & $\begin{array}{l}47.9 \mathrm{~N} \\
106.7 \mathrm{~W}\end{array}$ & 1350 & -35 & 33 & 60.4 & 180.1 & -0.0 & -0.0 \\
\hline
\end{tabular}

\section{Modeling and simulation}

After defining the appropriate geological location, a weather profile for hourly resolved 5 years average weather data was generated from the 'Meteonorm 7' climate databank [6] for this simulation. The nine differently shaped yurts gathered from existing and historical practice [1], [2] are built on the mathematical model, whereas there were similarities in between the shapes as all yurts' floor plan is round, has a central door and an opening on the top (Fig. 2).

To contrast, the shapes of those nine types of yurts, the orientation of the yurts were set identical, and identical climate station weather data in a whole year period was applied [7]. The floor areas are set same, albeit volume, 'top' opening, and door dimensions are different, following the shape form of the yurt. Under the material specifications, traditional materials of a wooden frame and felt (sheep wool) are considered in the simulations. 
The more detailed comparative analysis on volume, envelope area, door, and opening area and A/V-ratio (envelope surface Area divided by Volume), S/F-ratio (Surface area divided by Floor area) of traditional yurts are shown in Table II. The $13^{\text {th }}$ century Mongolian yurt shows the best results in the comparison, but Mongolian yurt has shown the closest result to $13^{\text {th }}$-century Mongolian yurt (Fig. 2). The best outcomes from each of the parameter are highlighted in grey as shown in Table II. Regarding the set points, according to the yurt nature, 'very poor' criteria were applied for thermal bridges, 'normal residential building' criteria was applied to the opening and the door schedules, furthermore, the indoor mean temperature was set between 21 and $25^{\circ} \mathrm{C}$.

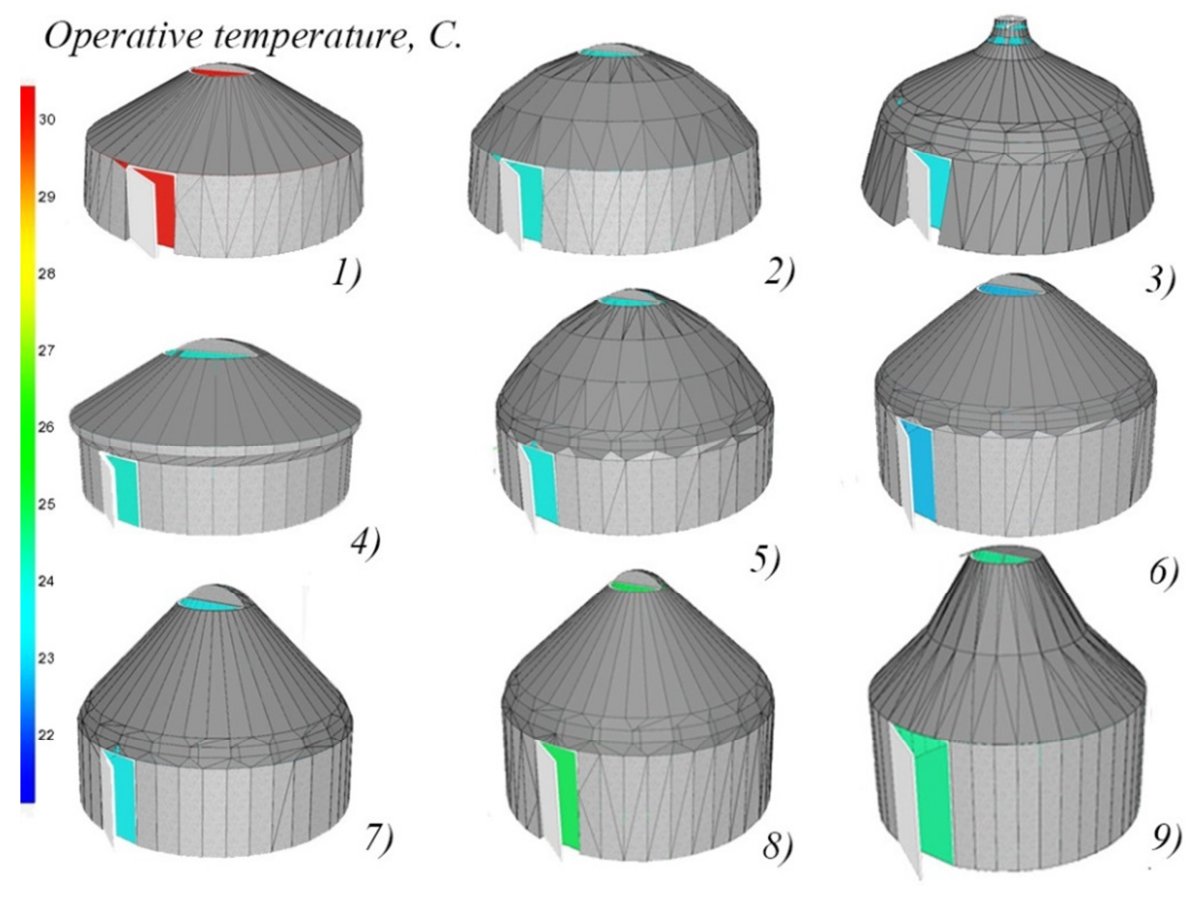

Fig. 2. Dynamic thermal simulation models of different types of traditional yurts with indicated operative temperatures. 1) Mongolian yurt, 2) $13^{\text {th }}$-century Mongolian yurt, 3) Hunnu yurt, 4) Inner Mongolian yurt, 5) Hungarian yurt, 6) Kazakh yurt, 7) Kyrgyz yurt, 8) Double wall yurt, 9) Afghanistan yurt [1], [2]

\section{Results and comparative analysis}

\subsection{The energy performance of the yurt}

In this section, used energy demand, delivered energy and energy balance of the nine yurts will be comparatively analysed on the basis of thermal dynamic simulations.

The $13^{\text {th }}$-century Mongolian yurt and Mongolian yurt are slightly different in the general shape information in Table II. However, the two yurts are significantly different 
for the delivered energy result due to heating and cooling which depend on the size of the top opening.

Table II

General information on traditional yurts

\begin{tabular}{|c|c|c|c|c|c|c|c|}
\hline Yurt type & $\begin{array}{l}\text { Floor } \\
\text { area } \\
{\left[\mathrm{m}^{2}\right]}\end{array}$ & $\begin{array}{l}\text { Volume } \\
{\left[\mathrm{m}^{3}\right]}\end{array}$ & $\begin{array}{l}\text { Envelope } \\
\text { area }\left[\mathrm{m}^{2}\right]\end{array}$ & $\begin{array}{c}\text { Average } \\
\text { U-value } \\
{\left[\mathrm{W} / \mathrm{m}^{2} \mathrm{~K}\right]}\end{array}$ & $\begin{array}{c}\text { Door } \\
\text { area } \\
{\left[\mathrm{m}^{2}\right]}\end{array}$ & $\begin{array}{c}\text { Opening } \\
\text { area } \\
{\left[\mathrm{m}^{2}\right]}\end{array}$ & $\begin{array}{c}\mathrm{S} / \mathrm{F} \\
{\left[\mathrm{m}^{2} / \mathrm{m}^{2}\right]}\end{array}$ \\
\hline Mongolian yurt & 28 & 50.3 & 82.8 & 1.374 & 1.38 & 0.83 & 1.96 \\
\hline Hunnu yurt & 28 & 58.1 & 86.7 & 1.336 & 1.39 & 0.83 & 2.10 \\
\hline $\begin{array}{l}\text { 13th century } \\
\text { Mongolian yurt }\end{array}$ & 28 & 49.7 & 81.2 & 1.333 & 1.42 & 0.27 & 1.90 \\
\hline $\begin{array}{l}\text { Inner Mongolian } \\
\text { yurt }\end{array}$ & 28 & 65.9 & 96.3 & 1.418 & 1.26 & 2.05 & 2.44 \\
\hline Yurt type & $\begin{array}{l}\text { Floor } \\
\text { area } \\
{\left[\mathrm{m}^{2}\right]} \\
\end{array}$ & $\begin{array}{c}\text { Volume } \\
{\left[\mathrm{m}^{3}\right]}\end{array}$ & $\begin{array}{l}\text { Envelope } \\
\text { area }\left[\mathrm{m}^{2}\right]\end{array}$ & $\begin{array}{c}\text { Average } \\
\text { U-value } \\
{\left[\mathrm{W} / \mathrm{m}^{2} \mathrm{~K}\right]}\end{array}$ & $\begin{array}{c}\text { Door } \\
\text { area } \\
{\left[\mathrm{m}^{2}\right]}\end{array}$ & $\begin{array}{c}\text { Opening } \\
\text { area } \\
{\left[\mathrm{m}^{2}\right]}\end{array}$ & $\begin{array}{c}\mathrm{S} / \mathrm{F} \\
{\left[\mathrm{m}^{2} / \mathrm{m}^{2}\right]}\end{array}$ \\
\hline Hungarian yurt & 28 & 78.9 & 100.6 & 1.339 & 1.53 & 0.87 & 2.59 \\
\hline Kazahk yurt & 28 & 83.3 & 104.6 & 1.314 & 1.8 & 1.02 & 2.74 \\
\hline Kyrgyz yurt & 28 & 82.1 & 103.6 & 1.366 & 1.93 & 1.02 & 2.70 \\
\hline Double wall yurt & 28 & 95.1 & 112.5 & 1.315 & 2.36 & 0.54 & 3.02 \\
\hline Afghanistan yurt & 28 & 108.6 & 128.3 & 1.363 & 4.53 & 0.95 & 3.58 \\
\hline
\end{tabular}

The lighting $(0.14 \mathrm{kWh})$ and equipment $(0.36 \mathrm{kWh})$ show the same results in the simulation for all types of the yurt. As illustrated in Fig. 3 and Fig. 4, $13^{\text {th }}$-century Mongolian yurt shows the best result in system energy.

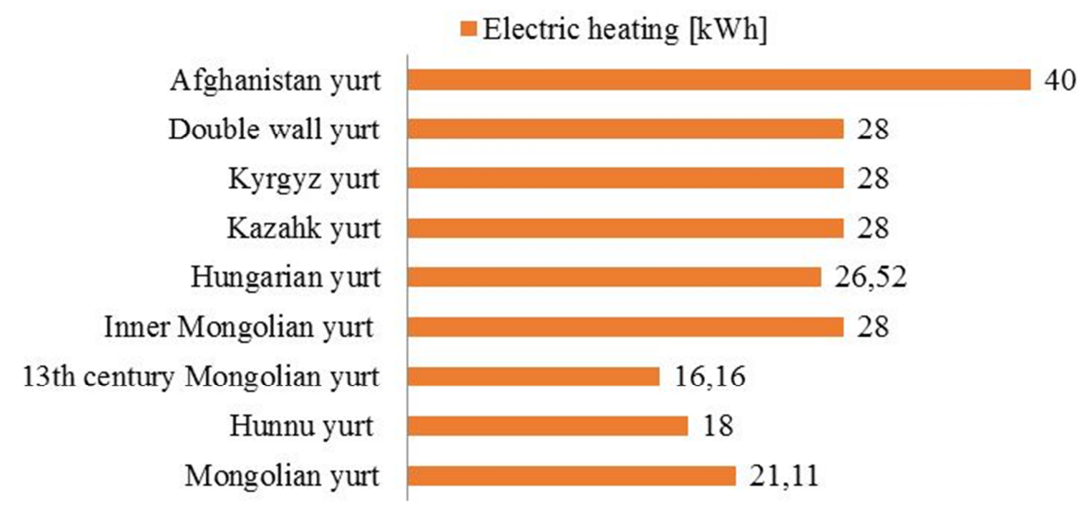

Fig. 3. Used heating energy demand in traditional yurts

The delivered (purchased) energy of traditional yurts is shown; also the best energy consumption which is the best results for heating (Fig. 5) and cooling (Fig. O) energy were performed in $13^{\text {th }}$-century Mongolian yurt and in Mongolian yurt respectively. 


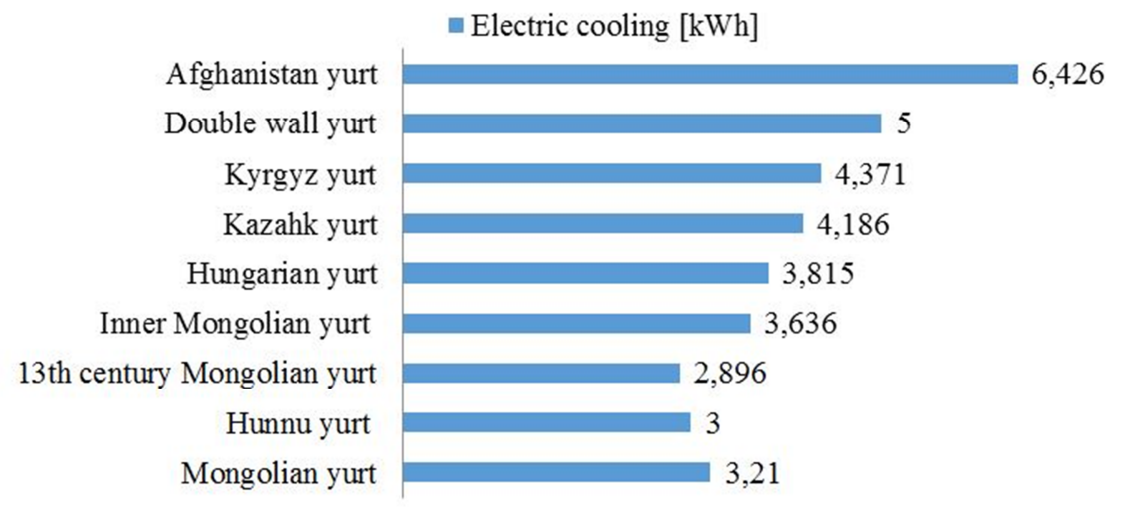

Fig. 4. Used cooling energy demand in traditional yurts

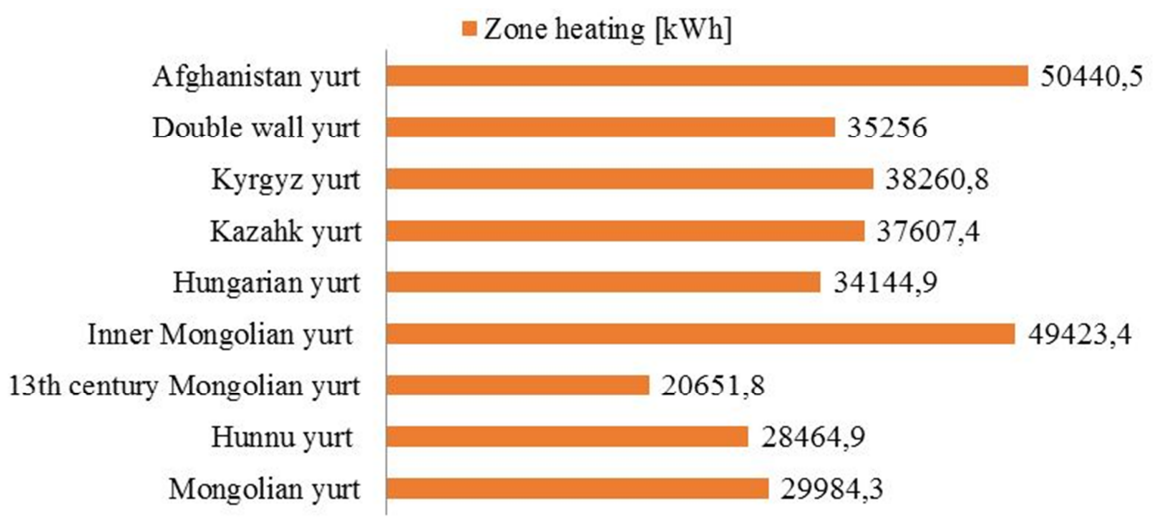

Fig. 5. Zone heating in the delivered energy of traditional yurt

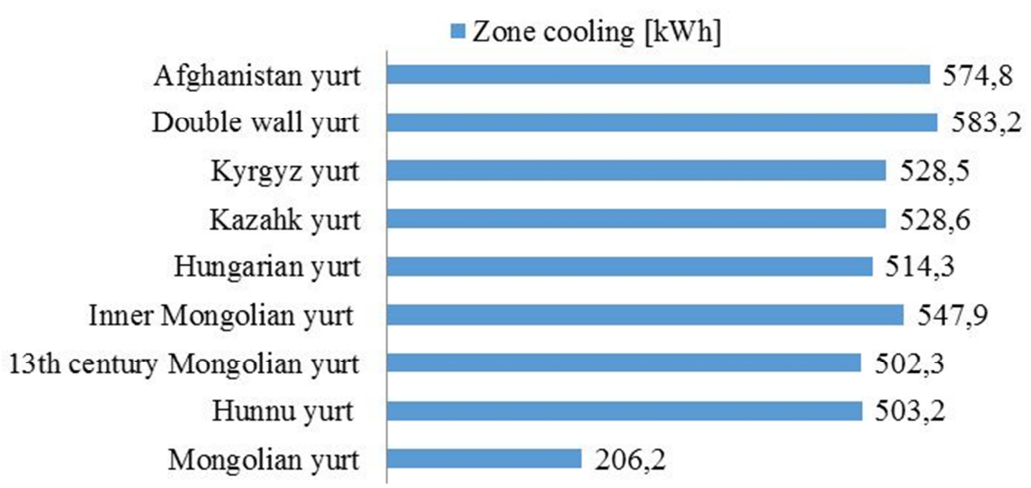

Fig. 6. Zone cooling in the delivered energy of traditional yurt

Pollack Periodica 14, 2019, 2 
As it is illustrated in Table III under the total heat loss indicator, Afghanistan yurt shows the largest and $13^{\text {th }}$ Mongolian yurt shows the smallest result.

Table III

The energy balance of traditional yurt

\begin{tabular}{|c|c|c|c|c|c|}
\hline & $\begin{array}{c}\text { Envelope \& } \\
\text { Thermal } \\
\text { bridges, kWh }\end{array}$ & $\begin{array}{c}\text { Internal Walls } \\
\text { and Masses, } \\
\text { kWh }\end{array}$ & $\begin{array}{l}\text { Window } \\
\& \text { Solar, } \\
\text { kWh }\end{array}$ & $\begin{array}{l}\text { Infiltra- } \\
\text { tion \& } \\
\text { Opening } \\
\mathrm{s}, \mathrm{kWh} \\
\end{array}$ & $\begin{array}{c}\text { Total } \\
\text { heat loss } \\
\%\end{array}$ \\
\hline \multicolumn{6}{|c|}{ Mongolian yurt } \\
\hline During heating & -19533.3 & -356.1 & -833.9 & -11180.6 & 59.0 \\
\hline During cooling & -38 & 15.5 & 49.3 & -21.3 & \\
\hline Rest of time & -101.3 & 6.8 & 9.5 & -41.1 & \\
\hline \multicolumn{6}{|c|}{ 13th-century Mongolian yurt } \\
\hline During heating & -18658.3 & -298.3 & -406.7 & -5797.2 & 46.6 \\
\hline During cooling & -30 & 9.9 & 22 & -8.3 & \\
\hline Rest of time & -102.3 & 1.5 & 5.3 & -18.3 & \\
\hline \multicolumn{6}{|c|}{ Hunnu yurt } \\
\hline During heating & -19658.3 & -356.7 & -826.9 & -11663.9 & 60.9 \\
\hline During cooling & -267.6 & 21 & 56.6 & -41.6 & \\
\hline Rest of time & -267.6 & 21 & 56.6 & -41.6 & \\
\hline \multicolumn{6}{|c|}{ Inner Mongolian yurt } \\
\hline During heating & -23505.6 & -489.7 & -1886.9 & -27483.3 & 99.1 \\
\hline During cooling & -248 & 42.7 & 117.3 & -58.8 & \\
\hline Rest of time & -219.7 & 4.9 & 18 & -70 & \\
\hline \multicolumn{6}{|c|}{ Hungarian yurt } \\
\hline During heating & -22283.3 & -383.6 & -866.1 & -13930.6 & 69.8 \\
\hline During cooling & -198.9 & 23.2 & 58.7 & -44.9 & \\
\hline Rest of time & -225.8 & 0.5 & 7.8 & -53.7 & \\
\hline \multicolumn{6}{|c|}{ Kyrgyz yurt } \\
\hline During heating & -24105.6 & -480 & -1063.9 & -16605.6 & 78.6 \\
\hline During cooling & -182.8 & 27.7 & 67.9 & -44.6 & \\
\hline Rest of time & -182.8 & 27.7 & 67.9 & -44.6 & \\
\hline \multicolumn{6}{|c|}{ Kazakh yurt } \\
\hline During heating & -23327.8 & -453.3 & -1040.6 & -16780.6 & 77.4 \\
\hline During cooling & -180.6 & 26.9 & 65.9 & -46.9 & \\
\hline Rest of time & -180.6 & 26.9 & 65.9 & -46.9 & \\
\hline \multicolumn{6}{|c|}{ Double wall yurt } \\
\hline During heating & -24891.7 & -485 & -755.8 & -13111.1 & 73.0 \\
\hline During cooling & -139.4 & 21.1 & 44.8 & -40.1 & \\
\hline Rest of time & -139.4 & 21.1 & 44.8 & -40.1 & \\
\hline \multicolumn{6}{|c|}{ Afghanistan yurt } \\
\hline During heating & -27627.8 & -928.3 & -1492.5 & -23958.3 & 100 \\
\hline During cooling & -116.8 & 41.6 & 83.7 & -49.2 & \\
\hline Rest of time & -116.8 & 41.6 & 83.7 & -49.2 & \\
\hline
\end{tabular}


The heat loss from the envelope and thermal bridges appear in between 34.1 and $51.5 \%$ heat loss from the opening are from 10.7 to $50.9 \%$. In respect to envelope and thermal bridges, Afghanistan yurt shows the highest heat loss and referring to infiltration and openings the Inner Mongolian yurt shows the highest heat loss. In the summertime, envelope and thermal bridges and top opening and infiltration provide cooling effect and Afghanistan yurt has biggest envelope area.

\subsection{The comfort of the yurt}

In this section, indoor air quality and thermal comfort will be analyzed through the facilitation of the simulation.

Indoor air quality: The result shows the bigger the volume, the lesser the $\mathrm{CO}_{2}$ concentration in yurts, which proves that there is a negative relation between volume and CO2. In Fig. 7 and Fig. 8 the $13^{\text {th }}$ century Mongolian yurt and Afghanistan yurts' $\mathrm{CO}_{2}$ level are shown as a representation as they have the highest and lowest results, respectively.

The maximum $\mathrm{CO}_{2}$ levels for each of the nine yurts are previously shown in the paper. In the simulation, scheduling for top opening coverage is set as open for daytime and closed for night time which effects to the yurt CO2 level. Accordingly, CO2 increases in the night much higher than the approvable level in the standard [8].

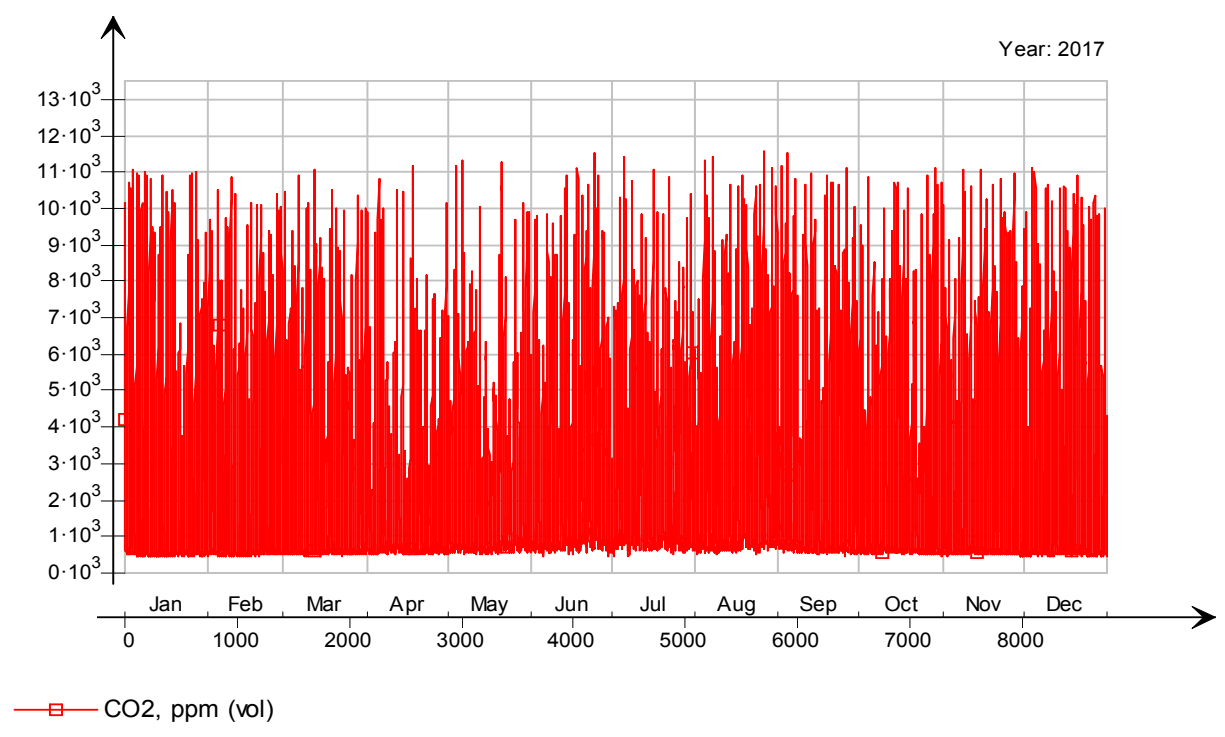

Fig. 7. $\mathrm{CO}_{2}$, ppm of the $13^{\text {th }}$-century Mongolian yurt, $(8760 \mathrm{~h})$

Thermal comfort according to EN 15251: Fig. 9 shows thermal comfort from the best to the unacceptable category depends on the operative temperature and illustrated 
the numbers of the occupancy hours. The most thermal comfortable yurt is the $13^{\text {th }}$ century Mongolian yurt.

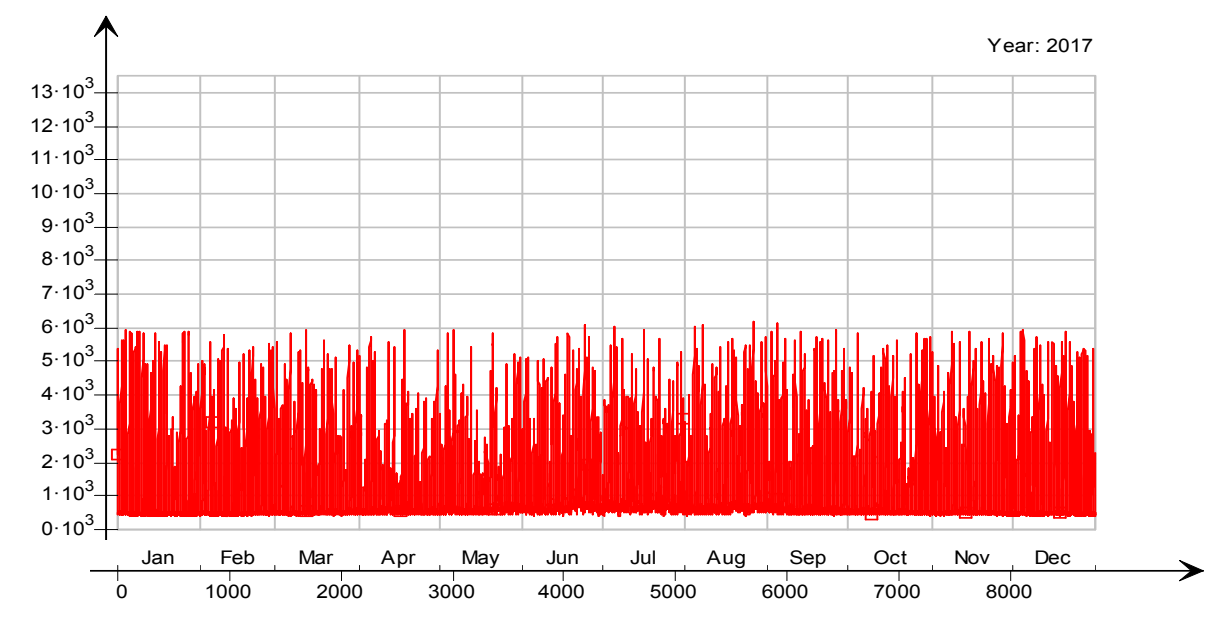

Fig. 8. $\mathrm{CO}_{2}$, ppm of Afghanistan yurt, $(8760 \mathrm{~h})$

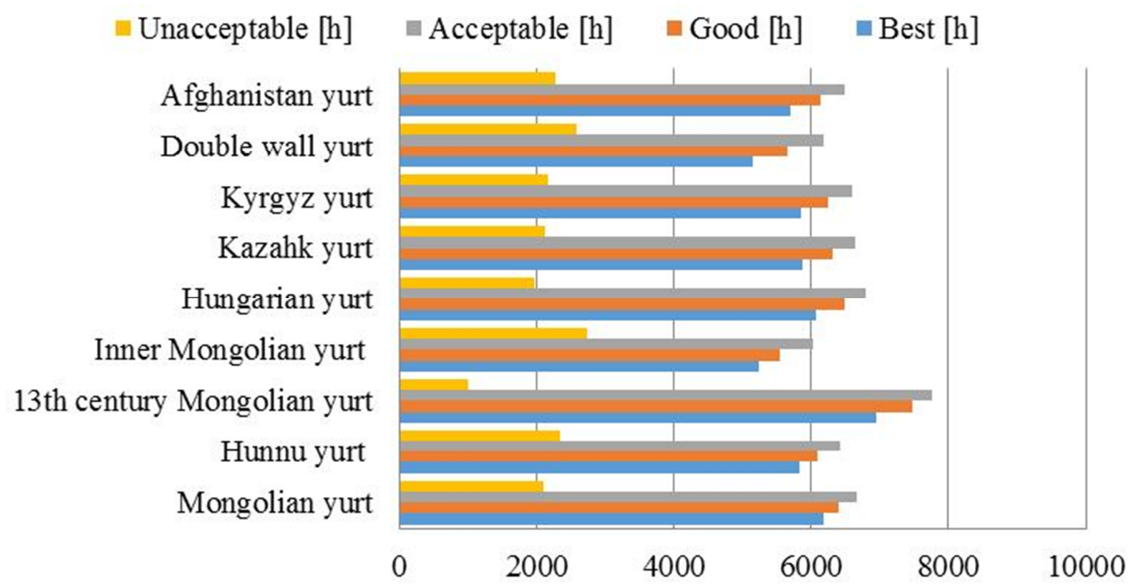

Fig. 9. Thermal comfort category and numbers of occupancy hours

The comparative result on the Predicted Mean Vote (PMV) is shown in Fig. 10, Fig. 11, the best-resulted yurt is the the13th-century Mongolian yurt (Fig. 10) Hunnu yurt, and Mongolian yurt is also good resulted in the simulation results but settled higher than the approvable level in the standard [9]. Afghanistan yurt (Fig. 11) shows the highest variance on PMV, because the PMV and the enveloped area have a direct relationship. 


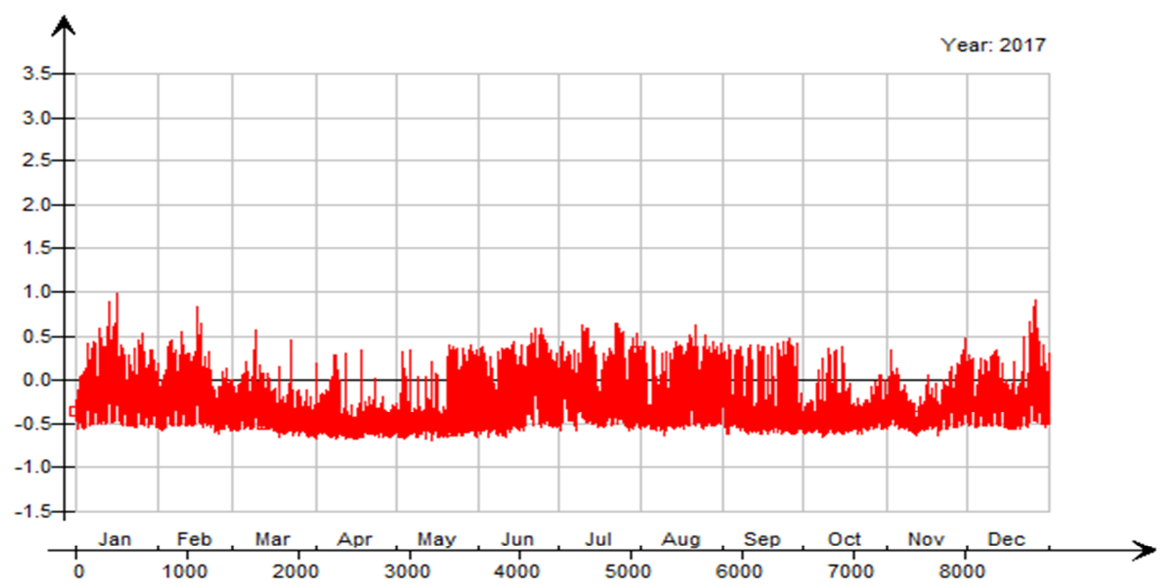

๑- PMV, Predicted Mean Vote

Fig. 10. PMV of a traditional $13^{\text {th }}$-century Mongolian yurt

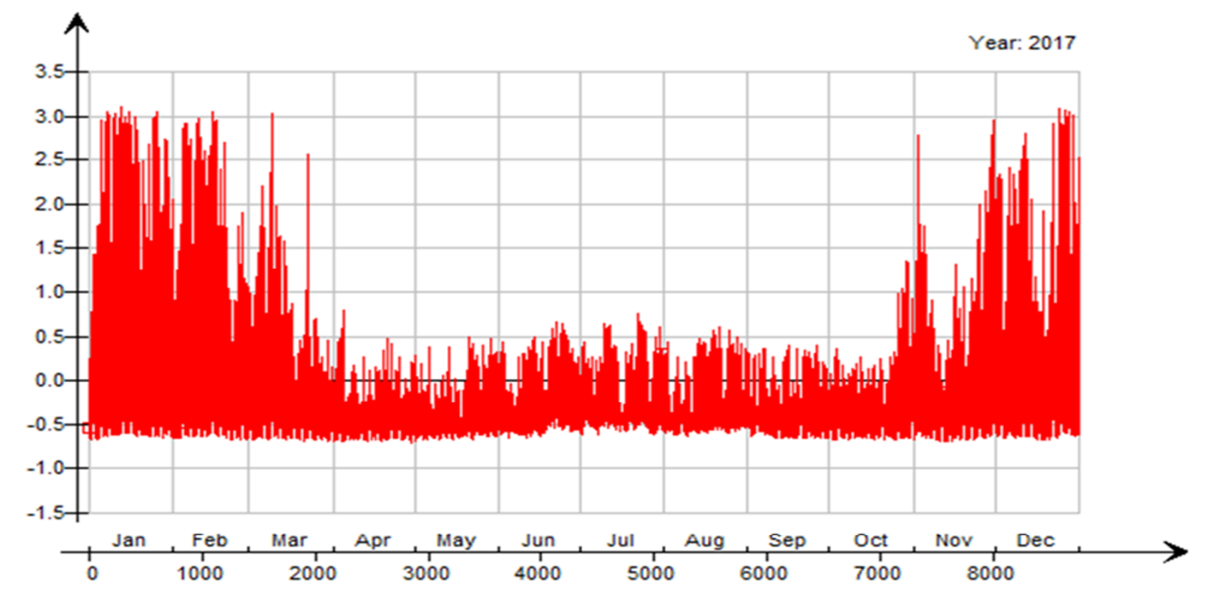

$\square-$ PMV, Predicted Mean Vote

Fig. 11. PMV of traditional Afghanistan yurt. $(8760 \mathrm{~h})$

\section{Conclusion}

In this study, the nine differently shaped yurts are simulated in the climate settings of Mongolian extreme conditions. However, to support the comparative analysis, the yurts' round plan is set identical and depending on the shapes the volumes differ. The study examines the energy and comfort as part of the research on finding optimal yurt for Mongolian condition. The simulation shows varying results depending on the 
criteria. Regarding surface/floor area, the $13^{\text {th }}$-century Mongolian yurt is best, followed by Mongolian yurt with a trivial difference. Also, $13^{\text {th }}$-century Mongolian yurt shows best results on system energy and delivered energy for heating. For cooling, Mongolian yurt shows the best result as it has a bigger top opening than $13^{\text {th }}$-century Mongolian yurt. The top opening helps the cooling by the ventilation. The greatest heat loss is obtained in the envelope and thermal bridge losses in all the models, while the second amount of the heat loss is generated by the top opening. In the summertime, these help the cooling.

The $\mathrm{CO}_{2}$ level of the yurt corresponds to the top opening schedule, during the night the top opening is covered and the $\mathrm{CO}_{2}$ level exceeds an acceptable level. The top opening has a crucial role in ventilation.

In consideration of thermal comfort, all yurts show lower than the acceptable level under PMV results, however, $13^{\text {th }}$-century Mongolian yurt better results in comparison to others. In general, $13^{\text {th }}$-century Mongolian yurt has better energy consumption and is more comfortable than other yurts in the settings of Mongolian climate. On the basis of this study, it has found that there is a room for improvement in modern Mongolian yurt from the angles of energy consumption and comfort. In the future researches $13^{\text {th }}$ century Mongolian yurt will be considered as the basis for further developments in accordance with its best results revealed from the current study.

\section{Open Access statement}

This is an open-access article distributed under the terms of the Creative Commons Attribution 4.0 International License (https://creativecommons.org/licenses/by/4.0/), which permits unrestricted use, distribution, and reproduction in any medium, provided the original author and source are credited, a link to the CC License is provided, and changes - if any - are indicated. (SID_1)

\section{Reference}

[1] Daajav B. Yurt as the origin of Mongolian architecture, (in Mongolian) Ulaanbaatar, Mongolia, Translated, 2006.

[2] Bat-Ulzii B., Dagmid O. Encyclopedia of the ger, the dwelling house of Mongols, (in Mongolian) 2nd Ed, Ulaanbaatar, Mongolia, Translated, 2016.

[3] Hausladen G., Liedl P, de Saldanha M. Building to suit the climate: a handbook, Birkhäuser, 2012.

[4] Mongolian building standard, Standard of the building for urban planning 30.01.04, Ministry of the infrastructure of Mongolia, Ulaanbaatar, Mongolia, 2004.

[5] Remund J. Accuracy of meteonorm 7, A detailed look at the model steps and uncertainties, 2015, http://www.meteonorm.com/images/uploads/downloads/Accuracy_of_Meteonorm 7.pdf, (last visited 21 April 2016).

[6] Baranyai B., Bachmann B., Kistelegdi I. Simulation-supported design of a Hungarian national sports center, Pollack Periodica, Vol. 11, No. 1, 2016, pp. 113-127.

[7] Radha C. H., Kistelegdi I. Thermal performance analysis of Sabunkaran residential building typology, Pollack Periodica, Vol. 12, No. 2, 2017, pp. 151-162. 
[8] CSN EN 13799, European standard, LPG equipment and accessories- Contents gauges for Liquefied Petroleum Gas (LPG) pressure vessels, 2014.

[9] Olesen B. W., Parsons K. C. Introduction to thermal comfort standards and to the proposed new version of EN ISO 7730, Energy and Buildings, Vol. 34, No. 6, 2002, pp. 537-548. 